\title{
Influence of Packaging and Cold Storage Conditions on the Physiochemical Properties of Barhi Date Fruits
}

\author{
Ramadan, B.R. ${ }^{1}$; Magda A.A. Selim ${ }^{1}$; K.S.A. Nagy ${ }^{2}$ and Zeinab S. Mohamed ${ }^{2}$ \\ ${ }^{1}$ Dept., Food and Science Technology, Faculty of Agriculture, Assuit University. \\ ${ }^{2}$ Dept., Food Engineering and Packaging, Food and Science Technology Institute, Agri- \\ culture Research Center.
}

Received on: $18 / 2 / 2020$

Accepted for publication on: 26/2/2020

\begin{abstract}
The fruit of date palm (Phoenix dactylifera L.) 'Barhi' is mainly harvested at Khalal stage, whereas fruits are physiologically mature, hard and crisp. Fruits are suitable for consumption at Khalal stage but due to their high moisture content, they are very perishable with low storage life. The physicochemical properties of Barhi fruits grown at Americana framers, Giza, Egypt, which packed inpolyamide/polyethylene (PA/PE), polyethylene (PE) and polypropylene (PP), under cold storage temperatures $\left(5 \pm 1^{\circ} \mathrm{C}\right)$ in response to vacuum and modified atmosphere packaging (MAP) with $\mathrm{N}_{2}$ were studied. Fruits were analyzed at four time intervals after packing $(0,3,6$ and 9 weeks) and evaluated for their quality characteristics: texture, weight loss, total soluble solids (TSS), pH, moisture content, acidity and sugar content. The obtained results showed that the joint fruits stored in PP packages under MAP conditions with nitrogen had recorded the highest quality. These fruits had lowest TSS, weight loss, $\mathrm{pH}$, acidity and moisture content and lowest change occurred in sugar content with a good texture.
\end{abstract}

Keywords: Barhi fruits, storage, modified atmosphere packing, quality attributes.

\section{Introduction}

Date (Phoenix dactylifera L.) is one of the oldest crops known to human in the Middle-East. Date palm has been cultivated at least since 6000 BC (AL-Qarawi et al., 2003). It's known that the date fruitis climacteric, and during the course of maturation, physiological changes occur that are attributed to the ethylene hormone (Chao and Krueger, 2007). Mehyar et al. (2014) explain that the Barhi date is a yellow variety of date that undergoes four physiological stages which are commonly described using Arabic terms, Kimri, Khalal (hard, yellowand edible), Rutab and Tamar. These phases of maturity are associated with distinctive texture, sensory, and chemical attributes.
In general, when fruits reach the Khalal stage, they are ready for trading as "fresh" date fruits but this applies only to those varieties which are sweet, with a low amount of tannin and low astringency (Barreveld, 1993). Some date cultivars are apposite for marketing at the Khalal stage including Barhi, Bereim, Hayany and Khalas (Glasner et al., 2002). The Barhi cultivar is one among the most favorable cultivars for marketing at the Khalal stage worldwide. Fresh dates are subject to biologicalprocesses such as respiration, ripening, and senescence, which can rapidly influence their quality characteristics (Mehyar et al., 2014).

During maturation of Barhi fruits, the moisture and tannins are reduced and reach their lowest levels 
at the Tamr stage. At Rutab stage fruit acidity reaches its highest level, while it's lowest at the Tamr stage, in contrast soluble solids, total and reducing sugars continuously increase throughout ripening. On the contrary, there is a continuous decrease in firmness, its reaches minimum values when the fruit is at the Rutab stage. At Tamr stage, Barhi fruits can still be quite soft (Al-Redhaiman, 2004 and Ismail et al., 2008).

The modified atmosphere packaging (MAP) includes modifying the concentrations of gases $\left(\mathrm{O}_{2}\right.$ and $\left.\mathrm{CO}_{2}\right)$ inside a package to preserve product quality by retaining moisture, lowering the rate of metabolic activity and retarding microbial deterioration (Caleb et al,. 2012).

Vacuum packaging (VP) and modified atmosphere packaging (MAP) are now being used for extend shelf-life and reduce the wastage of a wide range of fruits and vegetables. In the VP and MAP systems, the gas mixture surrounding fruits in the package is changed. The MAP technique can be employed to minimize such postharvest losses and maintain the quality of fresh fruits and vegetables (Mphahlele et al. 2016; OchoaVelasco and Guerrero-Beltran 2016; Anurag et al., 2016).

Al-Redhaiman (2004) stored Barhi date fruits full mature under three $\mathrm{CO}_{2}$ concentrations $(5,10$ or $20 \%$ ) at $0^{\circ} \mathrm{C}$, and showed that the fruits under $20 \% \mathrm{CO}_{2}$ have a statically longer storage period, lasted for 26 weeks. Furthermore, package type and storage temperature had significant effects on quality characteristics and shelf-life of date fruits; passive MAP resulted in the best maintenance of quality characters that were measured. Storage of Khalal dates under low temperatures e.g. storage in a refrigerator would retard metabolic reactions, respiration rate and ethylene production and help to prolong fruit shelf-life (Mortazavi et al., 2007).

Few trials have been carried out to improve the storage period and maintain fruit quality by using low temperatures (Al-Yahia, 1986), coating of fruits with polypropylene films (Thompson and Abboodi, 2003) or storing them in polyethylene bags (Hegazy et al., 2003).

Mortazavi et al. (2010) concluded the significant improvement in postharvest storage of Khalal Barhi date fruits that can be achieved, under modified atmosphere conditions. A conservative recommendation to minimize quality losses would be to keep the Khalal fruits under $5 \% \mathrm{CO}_{2}$ level during storage.

Alsawmahi et al. (2018) showed that MAP can be effectively employed to preserve the quality and improve the shelf-lifeof Barhi fruits using polypropylene (PP) as the packaging material during storage for 2 weeks at $5^{\circ} \mathrm{C}$.

\section{Materials and Methods \\ Materials:}

Fruits of Barhi date cultivar at Khalal stage were purchased from Americana Framers at Giza, Egypt, during August, 2018 and after quick precooling, fruits were transported to the laboratory on the same day. Any damaged, crumbled fruits and fruits with Rutab spots were removed. The healthy fruits of uniform size and appearance were cleaned prior to packaging. Polyamide/Polyethylene (PA/PE), Polyethylene (PE) and 
Polypropylene (PP) plastic containers with a wall thickness of $20 \mu \mathrm{m}$ were obtained from Food Engineering and Packaging Department, Agricultural Research Center, Giza. Fruits were evaluated every 3 weeks. The control sample was fresh Barhi fruits on zero day, at thestart of various experiments.

\section{Packing under modified atmos- phere}

Fruits were divided into eighteen lots, every one lot was divided into three replicates of 20 fruits $(200 \pm 5 \mathrm{~g})$. Each set of three replicates was put into a dish tray and placed in a container (PA/PE), (PE) and (PP) plastic bag $(17 \times 32 \mathrm{~cm})$. Some techniques are used for treating dates before storage, as follows (Table, 1).

Barhi fruits were packed in PA/PE, PE and PP containers and tightly closed (control), Barhi fruits were packed in PA/PE, PE and PP containers under vacuum and Barhi fruits were treated by nitrogen gas. All samples were stored at $5 \pm 1{ }^{\circ} \mathrm{C}$ for 9 weeks.

All active MAP treatments were performed by creating a vacuum in a Henkelman vacuum pack instrument (200A) followed by flushing the gas mixture 1 bar pressure before heat sealing and $\mathrm{N}_{2}$ used as a balance gas.

Table 1. Barhi date samples, package types and treatments:

\begin{tabular}{|l|l|l|}
\hline \multicolumn{1}{|c|}{ Fruits } & \multicolumn{1}{|c|}{ Packages } & \multicolumn{1}{c|}{ Treatments } \\
\hline 1- Joint fruits & $1-\mathrm{PA} / \mathrm{PE}$ & 1- Control \\
2- Detached fruits & $2-\mathrm{PE}$ & 2- Vacuum \\
& $3-\mathrm{PP}$ & $3-\mathrm{N}_{2}$ \\
\hline
\end{tabular}

\section{Analytical methods:}

Moisture content, Brix, total acidity, $\mathrm{pH}$ value, sugar content, reducing and non-reducing sugar, ash and fiber were measured according to AOAC (2005). The fruits subjected to all treatments were weighed before and after storage, then the results were expressed as percentage of weight loss. Fruit texture was measured by a Texture analyzer.

\section{The experimental design and statis- tical analysis:}

The current study consisted of four experiments (four storage periods). Each one was factorial experiment arranged in randomized complete block design (RCBD) using two factors i.e. packages (PA/PE, $\mathrm{PE}$ and $\mathrm{PP}$ ) and treatments (control joint and detached, vacuum joint and detached, nitrogen joint and detached). A combined analysis overall storage periods was performed using SAS software version 9.2 (SAS, Institute 2008).

\section{Results and Discussion}

Physical properties of Barhi fruits:

The obtained data of physical properties of fresh Barhi fruits are shown in Table (2). The mean weight of fresh fruits, pulp and stone were $20.35,19.08$ and $1.27 \mathrm{~g}$, respectively. The percentage of fruit pulp and stone was 93.75 and 6.24, respectively. The mean values of fruit volume and texture were $18.94 \mathrm{~cm}^{3}$ and $521.5 \mathrm{~g} / \mathrm{cm}^{2}$, respectively. Total soluble solids (TSS) and $\mathrm{pH}$ values were $26.6 \%$ and 6.15 , respectively. 
Table 2. Physical properties of fresh Barhi fruits at Khalal stage:

\begin{tabular}{|l|c|}
\hline \multicolumn{1}{|c|}{ Property } & Value \\
\hline Fruit weight $(\mathrm{g})$ & 20.35 \\
\hline Pulp weight $(\mathrm{g})$ & 19.08 \\
\hline Stone weight $(\mathrm{g})$ & 1.27 \\
\hline Pulp \% & 93.75 \\
\hline Stone \% & 6.24 \\
\hline Volume $\left(\mathrm{Cm}^{3}\right)$ & 18.94 \\
\hline Texture $\left(\mathrm{g} / \mathrm{Cm}^{2}\right)$ & 521.5 \\
\hline TSS\% & 26.6 \\
\hline pH value & 6.15 \\
\hline
\end{tabular}

* Mean of three replicates.

\section{Chemical properties of Barhi fruits:}

As shown in Table (3) the fresh Barhi fruits had high moisture content $(61.9 \%)$, this indicates that these fruits were highly perishable.The mean value of acidity was $0.09 \%$. Total sugar content was $74.2 \%$, and the non-reducing sugar was the predominate level $(66.6 \%)$, while the reducing sugar recorded the lowest value (7.6\%). Ash and fiber of the studied fruits were 1.2 and $7.35 \%$, respectively.

Table 3. Chemical properties of fresh Barhi fruits at Khalal stage:

\begin{tabular}{|l|c|}
\hline \multicolumn{1}{|c|}{ Component $^{*}(\%)$} & Value $^{* *}$ \\
\hline Moisture & 61.90 \\
\hline Acidity & 0.09 \\
\hline Total sugar & 74.20 \\
\hline Non-Reducing sugar & 66.60 \\
\hline Reducing sugar & 7.60 \\
\hline Ash & 1.20 \\
\hline Fiber & 7.35 \\
\hline
\end{tabular}

*On dry weight basis, except moisture and acidity.

**Mean of three replicates.

\section{Effect of packaging, treatments and storage periods on physical proper- ties of fresh Barhi fruits:}

Effect of packaging materials; Polyamide/Polyethylene (PA/PE),
Polyethylene (PE) and Polypropylene (PP) used for making containers on different quality characteristics of fresh Barhi fruits stored for 9 weeks at $5 \pm 1^{\circ} \mathrm{C}$ was found in Table (4). The control sample was fresh Barhi at zero time of the storage.

\section{Texture}

The measured initial texture of fruit at the start of experiment was $521.17 \mathrm{mg} / \mathrm{cm}$. Date fruits at Khalal stage had a hard and crisp texture. When the fruits changed to Rutab stage, its texture decreased. Mortazavi et al. (2010) reported that MAP caused minimum changes up to Rutab stage of fruits with maximum texture.

The interaction between packages, treatments and storage periods (Table, 4) had a significantly affected on texture. The lowest values were obtained by joint fruits stored in PP packages under MAP conditions with nitrogen (521.07, 508.50 and 495.57 $\mathrm{mg} / \mathrm{cm}^{3}$ ), while the highest values were obtained by control detached fruits stored in $\mathrm{PA} / \mathrm{PE}$ packages $\left(512.27,471.33\right.$ and $\left.436.30 \mathrm{mg} / \mathrm{cm}^{3}\right)$ at 3, 6 and 9 weeks, respectively. A similar trend was observed by AlRedhaiman (2004).

The Khalal fruits that lose their hard and crisp texture have reduced quality and attract lower prices. Softening of fruit texture is related to activation of pectin decomposing enzymes such as poly-galactronase (PG) which hydrolyses $\alpha$ (1-4) linkage between galactronic acid residues in pectin (Wills, 1998). Changed gas mixture surrounding fruits under modified atmosphere packaging caused slowing enzymatic reactions of fruits such as softening (Kader et al., 1989). 
Table 4. Effect of interaction between packages, treatments and storage period on texture and weight loss on fresh Barhi fruits":

\begin{tabular}{|c|c|c|c|c|c|c|c|}
\hline \multirow{3}{*}{ Storage period } & \multirow{3}{*}{ Treatments } & \multicolumn{3}{|c|}{ Texture } & \multicolumn{3}{|c|}{ Weight loss (\%) } \\
\hline & & & Packages & & & Packages & \\
\hline & & PA/PE & $\mathbf{P E}$ & PP & PA/PE & $\mathbf{P E}$ & PP \\
\hline Zero time & & $521.17^{\mathrm{abc}}$ & $521.17^{\mathrm{abc}}$ & $521.17^{\text {bcd }}$ & $0.00^{\mathrm{kT}}$ & $0.00^{\mathrm{jl}}$ & $0.00^{1 \mathrm{jkT}}$ \\
\hline \multirow{6}{*}{3 weeks } & Control-A & $512.38^{\mathrm{abc}}$ & $514.90^{\mathrm{abc}}$ & $514.93^{\text {abcd }}$ & $5.05^{\mathrm{efg}}$ & $4.90^{\mathrm{tgh}}$ & $4.55^{\mathrm{fgh}}$ \\
\hline & Control-B & $512.27^{\mathrm{abc}}$ & $513.17^{\mathrm{abc}}$ & $514.40^{\mathrm{abc}}$ & $5.31^{\text {cde }}$ & $5.71^{\mathrm{jkl}}$ & $4.90^{\mathrm{ijk}}$ \\
\hline & Vacuum-A & $514.30^{\mathrm{abc}}$ & $515.37^{\mathrm{abc}}$ & $517.90^{\mathrm{abc}}$ & $4.53^{\text {hij }}$ & $4.06^{\mathrm{h} j \mathrm{k}}$ & $3.82^{\mathrm{kl}}$ \\
\hline & Vacuum-B & $513.23^{\text {abcd }}$ & $515.37^{\text {bcd }}$ & $517.70^{\text {bcde }}$ & $4.82^{\text {ghi }}$ & $4.53^{\text {hij }}$ & $4.24^{1 \mathrm{jk}}$ \\
\hline & Nitrogen-A & $520.53^{\mathrm{abc}}$ & $520.73^{\text {abcd }}$ & $521.07^{\text {cde }}$ & $3.75^{\mathrm{ijk}}$ & $3.03^{\mathrm{ijkI}}$ & $2.47^{\mathrm{jk} I}$ \\
\hline & Nitrogen-B & $519.57^{\mathrm{abc}}$ & $520.27^{\text {abcd }}$ & $520.70^{\text {cde }}$ & $4.02^{1 \mathrm{jk}}$ & $3.52^{\mathrm{jl}}$ & $2.54^{\mathrm{jk}}$ \\
\hline \multirow{6}{*}{6 weeks } & Control-A & $471.70^{\text {abcd }}$ & $469.20^{\mathrm{abcd}}$ & $485.03^{\mathrm{bcd}}$ & $5.62^{\mathrm{abc}}$ & $5.58^{\mathrm{abc}}$ & $5.27^{\text {cde }}$ \\
\hline & Control-B & $471.33^{\text {bcde }}$ & $480.90^{\text {bcde }}$ & $483.60^{\text {bcde }}$ & $5.85^{\text {def }}$ & $5.75^{\mathrm{efg}}$ & $5.45^{\mathrm{efg}}$ \\
\hline & Vacuum-A & $480.50^{\mathrm{def}}$ & $483.90^{\text {def }}$ & $489.43^{\text {defg }}$ & $5.07^{\mathrm{efg}}$ & $4.84^{\text {ghi }}$ & $4.52^{\text {hij }}$ \\
\hline & Vacuum-B & $476.23^{\text {defg }}$ & $477.33^{\text {efgh }}$ & $486.90^{\mathrm{fgh}}$ & $5.21^{\mathrm{def}}$ & $5.30^{\text {ghi }}$ & $4.76^{1 \mathrm{jk}}$ \\
\hline & Nitrogen-A & $496.87^{\mathrm{abc}}$ & $507.23^{\mathrm{bcd}}$ & $508.50^{\text {cdef }}$ & $4.52^{\text {cde }}$ & $4.03^{\mathrm{def}}$ & $3.70^{\mathrm{efg}}$ \\
\hline & Nitrogen-B & $503.27^{\text {abc }}$ & $504.37^{\text {bcd }}$ & $506.70^{\text {cdef }}$ & $4.76^{\text {bcd }}$ & $4.52^{\text {cde }}$ & $4.04^{\mathrm{efg}}$ \\
\hline \multirow{6}{*}{9 weeks } & Control-A & $435.23^{\text {cdef }}$ & $465.73^{\text {cdef }}$ & $465.67^{\text {cdef }}$ & $6.74^{\text {tgh }}$ & $6.24^{\mathrm{tgh}}$ & $5.92^{\text {cdef }}$ \\
\hline & Control-B & $434.50^{\text {cdef }}$ & $462.30^{\text {cdef }}$ & $462.33^{\text {cdef }}$ & $7.09^{\text {tgh }}$ & $6.56^{\text {tgh }}$ & $6.08^{\text {cdef }}$ \\
\hline & Vacuum-A & $442.50^{\text {cdef }}$ & $472.50^{\text {cdef }}$ & $472.50^{\operatorname{defg}}$ & $5.75^{\text {fgh }}$ & $5.76^{\mathrm{tgh}}$ & $5.07^{\text {cdef }}$ \\
\hline & Vacuum-B & $436.30^{\text {cdef }}$ & $464.20^{\text {cdef }}$ & $464.23^{\text {defg }}$ & $6.32^{\text {tgh }}$ & $6.07^{\text {tgh }}$ & $5.54^{\text {cdet }}$ \\
\hline & Nitrogen-A & $467.63^{\text {abcd }}$ & $495.60^{\mathrm{abcd}}$ & $495.57^{\text {bcde }}$ & $5.23^{\text {def }}$ & $5.02^{\mathrm{efg}}$ & $4.75^{\text {fghi }}$ \\
\hline & Nitrogen-B & $463.43^{\text {bcde }}$ & $492.13^{\text {bcde }}$ & $492.10^{\text {cdef }}$ & $5.52^{\operatorname{def}}$ & $5.25^{\mathrm{efg}}$ & $4.92^{\text {tghi1 }}$ \\
\hline & \multicolumn{3}{|c|}{6.68} & \\
\hline
\end{tabular}

- A: joint fruits, B: detached fruits.

- PA/PE: Polyamide/polyethylene, PE: polyethylene and PP: polypropylene.

*Mean of three replicates.

- Means followed by the same small letter(s) do not significantly different at 0.05 level of probability.

\section{Weight loss}

Data in Table (4) showed that interaction betweenpackages, treatments and storage period under MAP had a significant affected on weight loss. The highest weight loss were recorded inthe detached Barhi fruits (control B) stored in PA/PE packages were 5.31, 5.85 and $7.09 \%$ while, the lowest losses were found in joint fruits stored in PP packages under MAP conditions with nitrogen (nitrogen A) which recorded 2.47, 3.70 and $4.75 \%$, at 3, 6 and 9 weeks, respectively. Fruits at Khalal stage have high moisture content and active metabolism so unfavorable factors that cause water evaporation from fruits, increase weight loss (Mortazavil et al., 2007). Similar results were obtained by Al-Yahia (1986), he reported that Barhi fruit weight loss, which occurred during storage period, is most probably due to fruit water loss. Weight loss is a physiological event caused by loss of water from the fruit surface to the surrounding atmosphere and loss of carbon on formation of $\mathrm{CO}_{2}$ during respiration (Mortazavi1 et al. 2010 and Rizzo and Muratore, 2009).

\section{Total soluble solids (TSS)}

The initial TSS of Barhi fruits measured at the start of experiment was $26.68 \%$ (Table, 5). The same data demonstrated that the interaction between packages, treatments and storage period on TSS of fruits had a 
significantly affected. In all treatments TSS increased by increment the storage period, (Mortazavi et al., 2007). The lowest increment values were obtained by joint fruits stored in PP packages under MAP conditions with nitrogen were 26.81, 27.79 and $27.78 \%$, while, the highest increment values were obtained by the detached fruits (control) stored in PA/PE packages were $28.52,29.35$ and $30.54 \%$ at 3,6 and 9 weeks, respectively. This increase could be due to the conversion of some insoluble compounds into soluble compounds (such as the conversion of proto-pectin into pectin), or as a result of the water loss from the fruits, and thus lower moisture contents as shown by Thompson and Abboodi (2003). These results are agreement with Al-Kahtani et al. (1998); Afoakwa and Sefa-Dedeh (2001) and Azelmat et al. (2005); they reported that the TSS content in date fruits increased gradually with the increase of storage time. The TSS is one of the most important maturity and quality markers in variousfruits, specially date fruits at Khalal stage, (Barreveld, 1993).

\section{pH value}

The measured initial $\mathrm{pH}$ value of Barhi fruits at the start of experiment was 6.50 (Table, 5). As the storage period increased, $\mathrm{pH}$ decrease in the MAP samples stored at $5 \pm 1^{\circ} \mathrm{C}$. Data in Table (5) revealed that the interaction between packages, treatments and storage period had a significant effect on $\mathrm{pH}$ values. The highest values were recorded by control detached fruits stored in $\mathrm{PA} / \mathrm{PE}$ packages were $6.46,6.42$ and 6.38 while, the lowest values were obtained by joint fruits stored in PP packages under MAP conditions with nitrogen were $6.37,6.34$ and 6.32 , at 3,6 and 9 weeks, respectively. Aleid et al. (2014) reported that the continuous fall in $\mathrm{pH}$ during storage period demonstrated that both oxidative and nonoxidative mechanisms might be the cause for $\mathrm{pH}$ changes.

According to Baloch et al. (2006), the $\mathrm{pH}$ of Dhakki dates stored at $40^{\circ} \mathrm{C}$ for 4 months gradually declines in samples stored under air, $\mathrm{O}_{2}$ or $\mathrm{N}_{2}$. A pH value decrease of Sayer dates stored at $30^{\circ} \mathrm{C}$ under different MAP conditions less pronounced than that obtained in control sample DehghanShoar et al. (2010). Therefore, the $\mathrm{pH}$ reduction was mostly due to $\mathrm{CO}_{2}$ solubility in the fruits' flesh, and to the activity of microorganisms and insects. 
Table 5. Effect of interaction between packages, treatments and storage period on TSS and pH on fresh Barhi fruits" :

\begin{tabular}{|c|c|c|c|c|c|c|c|}
\hline \multirow{3}{*}{ Storageperiod } & \multirow{3}{*}{ Treatments } & \multicolumn{3}{|c|}{ TSS\% } & \multicolumn{3}{|c|}{ pH } \\
\hline & & \multicolumn{3}{|c|}{ Packages } & \multicolumn{3}{|c|}{ Packages } \\
\hline & & PA/PE & PE & $\mathbf{P P}$ & $\mathbf{P A} / \mathbf{P E}$ & PE & PP \\
\hline Zero time & & $26.68^{\mathrm{abc}}$ & $26.68^{\text {bcd }}$ & $26.68^{\mathrm{cde}}$ & $6.50^{\mathrm{abc}}$ & $6.50^{\mathrm{abc}}$ & $6.50^{\mathrm{abc}}$ \\
\hline \multirow{6}{*}{3 weeks } & Control-A & $28.23^{\mathrm{def}}$ & $28.01^{\mathrm{def}}$ & $28.04^{\mathrm{de}}$ & $6.43^{\text {bcd }}$ & $6.41^{\mathrm{bcd}}$ & $6.42^{\text {bcd }}$ \\
\hline & Control-B & $28.52^{\text {cde }}$ & $28.35^{\text {cde }}$ & $28.23^{\mathrm{def}}$ & $6.46^{\mathrm{bc}}$ & $6.43^{\mathrm{bc}}$ & $6.42^{\mathrm{bcd}}$ \\
\hline & Vacuum-A & $27.54^{\text {efg }}$ & $27.49^{\text {efg }}$ & $27.37^{\text {cde }}$ & $6.41^{\text {def }}$ & $6.39^{\mathrm{def}}$ & $6.37^{\text {defg }}$ \\
\hline & Vacuum-B & $27.96^{\mathrm{fgh}}$ & $27.85^{\text {efg }}$ & $27.52^{\text {efg }}$ & $6.41^{\mathrm{cde}}$ & $6.40^{\text {cde }}$ & $6.40^{\text {cdef }}$ \\
\hline & Nitrogen-A & $27.12^{\mathrm{abc}}$ & $26.95^{\mathrm{abc}}$ & $26.81^{\text {bcd }}$ & $6.38^{\mathrm{efg}}$ & $6.37^{\mathrm{efg}}$ & $6.37^{\text {efgh }}$ \\
\hline & Nitrogen-B & $27.47^{\text {bcd }}$ & $27.41^{\mathrm{bcd}}$ & $27.05^{\mathrm{def}}$ & $6.39^{\mathrm{def}}$ & $6.38^{\mathrm{def}}$ & $6.39^{\text {defg }}$ \\
\hline \multirow{6}{*}{6 weeks } & Control-A & $28.96^{\mathrm{abc}}$ & $28.75^{\text {bcd }}$ & $28.38^{\text {cde }}$ & $6.41^{\text {cde }}$ & $6.40^{\text {cde }}$ & $6.39^{\mathrm{def}}$ \\
\hline & Control-B & $29.35^{\mathrm{abc}}$ & $28.92^{b c d}$ & $28.75^{\mathrm{def}}$ & $6.42^{\text {bcd }}$ & $6.42^{\text {bcd }}$ & $6.42^{\text {cde }}$ \\
\hline & Vacuum-A & $28.43^{\text {cde }}$ & $28.37^{\text {cde }}$ & $27.99^{\mathrm{def}}$ & $6.33^{\text {tgh }}$ & $6.35^{\mathrm{fgh}}$ & $6.37^{\text {ghi }}$ \\
\hline & Vacuum-B & $29.27^{\mathrm{bcd}}$ & $28.54^{\text {cde }}$ & $28.21^{\text {cde }}$ & $6.35^{\mathrm{efg}}$ & $6.35^{\text {efg }}$ & $6.38^{\text {efgh }}$ \\
\hline & Nitrogen-A & $28.78^{\text {cde }}$ & $28.46^{\mathrm{def}}$ & $27.79^{\text {efg }}$ & $6.35^{\text {tgh }}$ & $6.35^{\text {fgh }}$ & $6.34^{\mathrm{fgh}}$ \\
\hline & Nitrogen-B & $28.52^{\text {cde }}$ & $28.14^{\text {def }}$ & $28.26^{\mathrm{efg}}$ & $6.37^{\mathrm{fg}}$ & $6.36^{\mathrm{fg}}$ & $6.35^{\mathrm{fg}}$ \\
\hline \multirow{6}{*}{9 weeks } & Control-A & $29.73^{a b c}$ & $29.64^{\mathrm{bcd}}$ & $29.20^{\text {cde }}$ & $6.35^{\mathrm{efg}}$ & $6.39^{\mathrm{fgh}}$ & $6.37^{\mathrm{fgh}}$ \\
\hline & Control-B & $30.54^{\mathrm{abc}}$ & $29.99^{\mathrm{abc}}$ & $29.55^{\text {cde }}$ & $6.38^{\mathrm{efg}}$ & $6.37^{\mathrm{fgh}}$ & $6.37^{\text {tgh }}$ \\
\hline & Vacuum-A & $29.52^{\text {bcd }}$ & $29.32^{\text {cde }}$ & $28.56^{\mathrm{def}}$ & $6.30^{\text {ghi }}$ & $6.33^{\text {ghij }}$ & $6.35^{\text {ghij }}$ \\
\hline & Vacuum-B & $30.25^{a b c}$ & $30.18^{b c d}$ & $28.75^{\text {cde }}$ & $6.32^{\mathrm{fgh}}$ & $6.35^{\text {fghi }}$ & $6.38^{\text {fghi }}$ \\
\hline & Nitrogen-A & $28.55^{\mathrm{def}}$ & $28.48^{\text {cde }}$ & $27.78^{\text {efg }}$ & $6.32^{\mathrm{hij}}$ & $6.32^{\mathrm{hi}}$ & $6.32^{\text {hijk }}$ \\
\hline & Nitrogen-B & $28.20^{\text {efg }}$ & $28.07^{\text {cde }}$ & $27.88^{\mathrm{def}}$ & $6.34^{\mathrm{hg}}$ & $6.34^{\mathrm{hi}}$ & $6.32^{\text {hij }}$ \\
\hline \multicolumn{2}{|c|}{ R LSD } & \multicolumn{3}{|c|}{1.74} & \multicolumn{3}{|c|}{0.07} \\
\hline
\end{tabular}

- A: joint fruits, B: detached fruits.

- PA/PE: Polyamide/polyethylene, PE: polyethylene and PP: polypropylene.

*Mean of three replicates.

- Means followed by the same small letter(s) do not significantly different at 0.05 level of probability.

\section{Effect of packaging, treatments and} storage periods on chemical properties of fresh Barhi fruits

\section{Moisture content}

Data in Table (6) showed that interaction between packages, treatments and storage period had significantly affected on moisture content of the studied samples. The moisture wasdecreaseduring storage period. At the harvest the moisture content of fruits was $61.09 \%$. The highest moisture contents were obtained by control detached fruits stored in PA/PE packages $(55.40,52.30$ and $49.50 \%)$ while, the lowest values were obtained by joint fruits stored in PP packages under MAP conditions with nitrogen 59.20, 56.20 and $54.23 \%$, at 3, 6 and 9 weeks, respectively.

Loss of moisture was previously reported in date fruits during storage as they changed from the Kimri to Rutab stage (Tafti and Fooladi, 2005; Awad, 2011 and Iqbal et al., 2011). Moisture levels of fruits have been reported to remain more or less constant under low temperature storage, but prolonged storage often leads to a decrease in moisture content (Afoakwa and Sefa-Dedeh, 2001; Omoigho and Ikenebomeh, 2000 and Zare et al., 2002). Ihsanullah et al. (2005) reported that moisture 
content of date fruits packed in white polythene decreased from 14.1 to $9.7 \%$ over 5 months period. Khan et al. (2008) suggested that moisture content of dry date fruits decreased from 12.8 to $14.2 \%$ after 12 months storage at ambient temperature. However, Aleid et al.
(2014) observed that the significant increases in moisture content of Khalas and Sukkary cultivars, which could be attributed to the initially low level of moisture and the high TSS content in date fruits that would bound water leaving very little of free water to be lost.

Table 6. Effect of interaction between packages, treatments and storage periods on chemical properties on fresh Barhi fruits":

\begin{tabular}{|c|c|c|c|c|c|c|c|}
\hline \multirow{3}{*}{ Storage period } & \multirow{3}{*}{ Treatments } & \multicolumn{3}{|c|}{ Moisture content \% } & \multicolumn{3}{|c|}{ Acidity\% } \\
\hline & & \multicolumn{3}{|c|}{ Packages } & \multicolumn{3}{|c|}{ Packages } \\
\hline & & PA/PE & PE & PP & $\mathbf{P A} / \mathbf{P E}$ & PE & PP \\
\hline Zero time & & $61.09^{\mathrm{bcd}}$ & $61.09^{\mathrm{abc}}$ & $61.09^{\mathrm{abc}}$ & $0.09^{\mathrm{hi}}$ & $0.09^{\mathrm{hi}}$ & $0.09^{\text {hij }}$ \\
\hline \multirow{6}{*}{3 weeks } & Control-A & $56.40^{\text {bcde }}$ & $57.61^{\text {bcde }}$ & $56.70^{\text {cdef }}$ & $0.17^{\text {efg }}$ & $0.17^{\mathrm{efg}}$ & $0.15^{\text {hij }}$ \\
\hline & Control-B & $55.40^{\text {cdef }}$ & $55.90^{\mathrm{def}}$ & $56.30^{\text {def }}$ & $0.17^{\text {efg }}$ & $0.17^{\text {efg }}$ & $0.16^{\text {ghi }}$ \\
\hline & Vacuum-A & $57.40^{\text {cde }}$ & $57.51^{\text {cdef }}$ & $57.63^{\text {cdef }}$ & $0.15^{\mathrm{hij}}$ & 0.15 & $0.14^{\text {fgh }}$ \\
\hline & Vacuum-B & $57.70^{\text {cde }}$ & $57.07^{\mathrm{def}}$ & $57.30^{\text {def }}$ & $0.16^{\text {ghi }}$ & $0.16^{\text {ghi }}$ & $0.14^{\mathrm{fgh}}$ \\
\hline & Nitrogen-A & $59.45^{\mathrm{abc}}$ & $59.35^{\text {bcde }}$ & $59.20^{\text {bcde }}$ & $0.15^{\mathrm{h}}$ & $0.14^{\mathrm{fgh}}$ & $0.13^{\text {tghi }}$ \\
\hline & Nitrogen-B & $58.50^{\text {bcd }}$ & $58.32^{\text {cde }}$ & $58.25^{\text {def }}$ & $0.15^{\mathrm{h}}$ & $0.14^{\mathrm{fgh}}$ & $0.13^{\text {fghi }}$ \\
\hline \multirow{6}{*}{6 weeks } & Control-A & $53.70^{\text {cde }}$ & $54.20^{\mathrm{def}}$ & $54.50^{\mathrm{def}}$ & $0.23^{\text {cde }}$ & $0.25^{\mathrm{de}}$ & $0.22^{\mathrm{def}}$ \\
\hline & Control-B & $52.30^{\mathrm{def}}$ & $52.70^{\mathrm{def}}$ & $53.30^{\text {efg }}$ & $0.24^{\mathrm{bcd}}$ & $0.23^{\text {bcde }}$ & $0.24^{\mathrm{abcd}}$ \\
\hline & Vacuum-A & $54.93^{\mathrm{efg}}$ & $55.30^{\mathrm{efg}}$ & $55.70^{\mathrm{fgh}}$ & $0.22^{\mathrm{e}}$ & $0.21^{\mathrm{e}}$ & $0.21^{\text {ef }}$ \\
\hline & Vacuum-B & $54.03^{\mathrm{efg}}$ & $54.70^{\text {efg }}$ & $55.20^{\mathrm{fgh}}$ & $0.22^{\text {cde }}$ & $0.24^{\text {cde }}$ & $0.21^{\text {cde }}$ \\
\hline & Nitrogen-A & $56.47^{\text {cde }}$ & $56.30^{\mathrm{def}}$ & $56.20^{\text {efgh }}$ & $0.20^{\mathrm{f}}$ & 0.20 & $0.19^{\mathrm{fgh}}$ \\
\hline & Nitrogen-B & $55.17^{\mathrm{def}}$ & $55.70^{\text {defg }}$ & $55.40^{\text {fgh }}$ & $0.20^{\mathrm{f}}$ & 0.20 & $0.20^{\mathrm{fgh}}$ \\
\hline \multirow{6}{*}{9 weeks } & Control-A & $50.30^{\mathrm{efg}}$ & $50.70^{\mathrm{fgh}}$ & $51.30^{\mathrm{fgh}}$ & $0.27^{\mathrm{a}}$ & $0.28^{\mathrm{a}}$ & 0.27 \\
\hline & Control-B & $49.50^{\mathrm{fg}}$ & $52.87^{\mathrm{fg}}$ & $50.80^{\text {fgh }}$ & $0.28^{\mathrm{a}}$ & $0.26^{\mathrm{a}}$ & 0.28 \\
\hline & Vacuum-A & $51.70^{\mathrm{gh}}$ & $52.90^{\text {ghi }}$ & $53.20^{h i j}$ & $0.25^{\mathrm{bc}}$ & $0.26^{\mathrm{bc}}$ & $0.24^{\text {cde }}$ \\
\hline & Vacuum-B & $51.20^{\mathrm{gh}}$ & $52.30^{\text {ghi }}$ & $51.70^{\mathrm{hi}}$ & $0.25^{\mathrm{b}}$ & $0.25^{b}$ & $0.26^{\text {bd }}$ \\
\hline & Nitrogen-A & $53.90^{\mathrm{g}}$ & $55.17^{\text {gh }}$ & $54.23^{\text {ghi }}$ & $0.24^{\mathrm{d}}$ & $0.23^{\mathrm{d}}$ & $0.23^{\mathrm{de}}$ \\
\hline & Nitrogen-B & $53.20^{\mathrm{g}}$ & $55.03^{\text {gh }}$ & $54.10^{\text {ghij }}$ & $0.24^{\mathrm{cd}}$ & $0.23^{\mathrm{cd}}$ & $0.24^{\mathrm{def}}$ \\
\hline \multicolumn{2}{|c|}{ R LSD } & \multicolumn{3}{|c|}{4.43} & \multicolumn{3}{|c|}{0.04} \\
\hline
\end{tabular}

- A: joint fruits, B: detached fruits.

- PA/PE: Polyamide/polyethylene, PE: polyethylene and PP: polypropylene.

*Mean of three replicates.

- Means followed by the same small letter(s) do not significantly different at 0.05 level of probability.

\section{Acidity}

Data in Table (6) demonstrated that the interaction between packages, treatments and storage periods had significantly affect on fruit samples acidity. At harvest, the level of acidity was $0.09 \%$ and acidity was increased significantly throughout the evaluation period for all samples. The highest acidity $(0.17,0.24$ and $0.28 \%)$ was scored by control detached fruits stored in PA/PE packages while, the lowest values $(0.13,0.19$ and 0.23$)$, were scored by joint fruits stored in PP packages under MAP conditions with nitrogen at 3, 6 and 9 weeks, respectively. These results are agreement with Mortazavi et al. (2010) and Jemni et al. (2016). Wang et al. (1993) suggested that, the organic 
acid composition of fruits is of interest because of its influence on the sensory properties of fruits, even though they are minor components of fruits, in combination with sugars. However, generally during growth and maturation of date fruit the acid content tends to go down. Barreveld (1993) reported that upon storage and more specifically at the onset of deterioration, second generation organic acids are formed.

\section{Total sugar}

At the beginning of the experiment, total sugar content of Barhi fruits was $74.24 \%$ (Table, 7) and increased at different rates during storage. The obtained data demonstrated that the interaction between packages, treatments and storage period had a significantly affect on fruit total sugars. The highest change were occurred in control detached fruits stored in $\mathrm{PA} / \mathrm{PE}$ packages were $78.77,86.24$ and $87.30 \%$ while, the lowest change were occurred in joint fruits stored in PP packages under MAP conditions with nitrogen were $76.49,77.35$ and $78.74 \%$, at 3,6 and 9 weeks, respectively. These results are agreement with Al-Redhaiman, (2004) who found that an increase of total sugar in Barhi fruits stored at $0^{\circ} \mathrm{C}$ under 5,10 and $20 \% \mathrm{CO}_{2}$ concluding that $20 \% \mathrm{CO}_{2}$ was the best storage condition.

Table 7. Effect of interaction between packages, treatments and storage periods on total sugar on fresh Barhi fruits ${ }^{*}$ :

\begin{tabular}{|c|c|c|c|c|}
\hline \multirow{3}{*}{ Storage period } & \multirow{3}{*}{ Treatments } & \multicolumn{3}{|c|}{ Total sugar } \\
\hline & & \multicolumn{3}{|c|}{ Packages } \\
\hline & & $\mathbf{P A} / \mathbf{P E}$ & PE & PP \\
\hline Zero time & & $74.24^{\mathrm{abc}}$ & $74.24^{\text {bcd }}$ & $74.24^{\text {cde }}$ \\
\hline \multirow{6}{*}{3 weeks } & Control-A & $78.77^{\text {abcd }}$ & $80.23^{\mathrm{bcd}}$ & $79.32^{a b c}$ \\
\hline & Control-B & $79.27^{\mathrm{abc}}$ & $81.54^{\text {bcd }}$ & $80.25^{a b c}$ \\
\hline & Vacuum-A & $76.63^{\mathrm{cd}}$ & $78.45^{\text {def }}$ & $76.70^{\text {cde }}$ \\
\hline & Vacuum-B & $77.76^{\text {bcde }}$ & $79.27^{\text {cde }}$ & $78.54^{\text {bcde }}$ \\
\hline & Nitrogen-A & $75.40^{\mathrm{bc}}$ & $77.45^{\text {bcd }}$ & $76.49^{\text {abcd }}$ \\
\hline & Nitrogen-B & $76.31^{\text {bcd }}$ & $77.90^{\text {bcde }}$ & $76.73^{\text {bcd }}$ \\
\hline \multirow{6}{*}{6 weeks } & Control-A & $84.32^{\text {cdef }}$ & $83.16^{\mathrm{def}}$ & $80.53^{\text {defg }}$ \\
\hline & Control-B & $86.24^{\text {cdef }}$ & $83.96^{\text {def }}$ & $81.75^{\text {defg }}$ \\
\hline & Vacuum-A & $82.24^{\text {defg }}$ & $80.57^{\text {efgh }}$ & $78.90^{\text {efghi }}$ \\
\hline & Vacuum-B & $82.94^{\operatorname{defg}}$ & $81.25^{\text {efgh }}$ & $79.32^{\text {efghi }}$ \\
\hline & Nitrogen-A & $80.96^{\text {def }}$ & $78.52^{\text {efg }}$ & $77.35^{\text {def }}$ \\
\hline & Nitrogen-B & $81.35^{\mathrm{efg}}$ & $79.34^{\text {efg }}$ & $78.58^{\text {defg }}$ \\
\hline \multirow{6}{*}{9 weeks } & Control-A & $85.67^{\text {defg }}$ & $84.24^{\mathrm{efg}}$ & $82.50^{\text {fgh }}$ \\
\hline & Control-B & $87.30^{\text {defg }}$ & $85.45^{\text {efg }}$ & $83.73^{\text {fgh }}$ \\
\hline & Vacuum-A & $83.79^{\text {efg }}$ & $82.60^{\text {ghi }}$ & $80.21^{\text {ghij }}$ \\
\hline & Vacuum-B & $84.95^{\text {efg }}$ & $83.76^{\text {ghi }}$ & $80.96^{\text {ghij }}$ \\
\hline & Nitrogen-A & $81.33^{\operatorname{defg}}$ & $81.31^{\text {fghi }}$ & $78.74^{\text {cdef }}$ \\
\hline & Nitrogen-B & $82.55^{\operatorname{defg}}$ & $82.22^{\text {fghi }}$ & $79.55^{\text {defg }}$ \\
\hline \multicolumn{2}{|c|}{ R LSD } & & 6.57 & \\
\hline
\end{tabular}

- A: joint fruits, B: detached fruits.

- PA/PE: Polyamide/polyethylene, PE: polyethylene and PP: polypropylene.

${ }^{*}$ Mean of three replicates.

- Means followed by the same small letter(s) do not significantly different at 0.05 level of probability. 
Jemni et al. (2016) observed that the MAP and VP treatments had a significant effect on concentration of total sugars, of dates stored at $20^{\circ} \mathrm{C}$ for 30 days. Moreover, after storage, it was found a decrease of total sugars. These differences could be very probably due to different storage temperature, being more stimulated the respiration rate and global metabolism in our experiment at a considerably higher temperature. In fact, it is well known that sugars are excellent respiratory substrates.

\section{Conclusion:}

From the obtained results, it can be concluded that the cold storage and packing types could affect the quality of Barhi fruits. There were significant changes in quality properties were associated with storage. Detaching fruit from stalk showed trivial positive effects on preserve of the studied quality factors. The joint fruits stored in PP packages under MAP conditions with nitrogen recorded the best quality properties.

Utilization vacuum packing (VP) and modified atmosphere packing (MAP) of fresh Barhi date fruits to obtained the quality attributes need more studies, especially, regarding the health and economic benefits from this important fruit.

\section{References}

AOAC (2005). Official Methods of the Association of official Analytical Chemists $16^{\text {th }}$ Ed. Washington, D.C., U.S.A.

Afoakwa, E. O. and Sefa-Dedeh, S. (2001). Chemical composition and quality changes occurring in Dioscorea dumetorumpax tubers after harvest. Food Chem., 75: 85-91.

Ahmed, I. A. and Ahmed, A. K. (1995). Chemical composition of date va- rieties as influenced by the stage of ripening. Food Chem., 54: 305309.

Aleid, S. M.; Elansari, A. M.; Tang Zhen-Xing and Sallam, A. A. (2014). Effect of cold storage and packing type on Khalas and Sukkary dates quality. Adv. J. Food Sci. Technol., 6(5): 603-608.

Al-Kahtani, H. A.; Abu-Tarboush, H. M.; AlDryhim, Y. N.; Ahmed, M. A.; Bajaber, A.S.; ElShami, E. A. and El-Mojaddidi, M. A. (1998). Irradiation of dates: Insect disinfestations, microbial and chemical assessments and use of thermo luminescence. Radiat. Phys. Chem., 53: 181-187.

Al-Qarawi, A. A.; Ali, B. H.; Al-Mougy, S. A. and Mousa, H. M. (2003). Gastrointestinal transit in mice treated with various extracts of date (Phoenix dactylifera L.). Food and chem. Toxi. 41: 37-39.

Al-Redhaiman, K. N. (2004). Modified atmosphere improves storage ability, controls decay and maintains quality and antioxidant contents of Barhi date fruits. Food Agric. and Enviro. 2: 25-32.

Al-Redhaiman, K. N. (2005). Chemical changes during storage of Barhi dates under controlled modified atmosphere. Hort. since 40 (5): 1413-1415.

Alsawmahi1, O.N.; Al-Juhaimi, F.Y.; Alhamdan, A.M.; Ghafoor, K.; Ahmed, I.A.M.; Hassan, B. H.;Ehmed, K.A.; Diaeldin, A.; Younis, M.; Alashmawe, N. and Adiamo, O. Q. (2018). Enzyme activity, sugar composition, microbial growth and texture of fresh Barhi dates as affected by modified atmosphere packaging. J. Food Sci. Technol. 55:4492-4504.

Al-Yahia, S. A. (1986). Quality change of 'Barhy' dates during storage at Bisr stage. Proc. of the $2^{\text {nd }}$ Symp. 
on the Date Palm in Saudi Arabia.pp: 3-6.

Anurag, R.K.; Manjunatha, M.; Jha, S.N. and Kumari, L. (2016). Storage quality of shelled green peas under different storage conditions. J. Food Sci. Technol. 53(3):16401648.

Awad, M.A. (2011). Growth and compositional changes during development and ripening of early summer "Lonet-Mesaed" date palm fruits. J. of Food, Agric. and Env., 9: 4044.

Azelmat, K.; Sayah, F.; Mouhib, M.; Ghailani, N. and El-Garrouj, D. (2005). Effect of gamma irradiation on fourth-instar Plodia interpunctella (Hubner) (Lepidoptera: Pyralidae). J. Stored Prod. Res., 41: 423-431.

Baloch, M.K.; Saleem, S.A.; Baloch, A.K.; Baloch, W.A. (2006). Impact of controlled atmosphere on the stability of Dhakki dates. LWTFood Sci. Technol. 39: 671-676.

Barreveld, W.H. (1993). Date Palm Products. Agricultural Services Buletin No 101, F.A.O., Rome: 150.

Caleb, O.J.; Opara, U.L. and Witthuhn, C. R. (2012). Modified atmosphere packaging of pomegranate fruit and arils: a review. Food Bioprocess Technol. 5:15-30.

Chao, C.T. and Krueger, R. R. (2007). The date palm (Phoenix dactylifera L.): overview of biology, uses, and cultivation. Hort Sci. 42:10771082.

Dehghan-Shoar, Z.; Hamidi-Esfahani, Z. and Abbasi, S. (2010). Effect of temperature and modified atmosphere on quality preservation of Sayer date fruits (Phoenix dactylifera L.). J. Food Process Preserv34 (2): 323-334.

El-Rayes, D.A. (2009). Effect of carbon dioxide-enriched atmosphere dur- ing cold storage on limiting antioxidant losses and maintaining quality of 'Barhy' date fruits. Met., Env.\& Arid Land Agric. Sci., 20 (1): 3-22.

Glasner, B., Botes, A., Zaid, A. and Emmens, J. (2002). Date harvesting, packinghouse management and marketing aspects. In: A. Zaid (ed.), Date palm cultivation. FAO Plant Production and Protection Paper, No: 156. FAO, Rome: 237267.

Hegazy, M.K., Fahmy, M.A., Sobaih, M.A. and Abdul-Samad, M.A. (2003). Effect of some postharvest treatments on Zagloul date fruits during storage. Proceedings of the International Conference on the Date Palm, 16-19 Sep., 2003, King Saud Univ., Qassim, Kingdom of Saudi Arabia. pp. 353-362.

Ihsanullah, I.; Iqbal, Y. and Khattak, T.N. (2005). Effect of various irradiation doses on some nutrients of Pakistani date. J. Radioanal. Nucl. Ch., 266: 361-366.

Iqbal, M.; Imaranullah, M. and Niamatullah, M. (2011). Physiochemical characteristics of date palm (Phoenix dactylifera L.) cultivars at various maturity stages under environmental conditions of dera Ismail Khan. J. of Agric. Res., 49: 249-259.

Ismail, B.; Haffar, I.; Baalbaki, R. and Henry, J. (2008). Physico-chemical characteristics and sensory quality of two date varieties under commercial and industrial storage conditions. LWT-Food Sci. Technol., 41: 896-914.

Jemni, M.; Chniti, S.; Harbaoui, K. Ferchichi, A. and Artés, F. (2016). Partial vacuum and active modified atmosphere packaging for keeping overall quality of dates.J. of new Sci., Agri. and Biot. 29(1):1656-1665. 
Kader, A.A., Zagory, D. and Kerbel, E. L. (1989). Modified atmosphere packaging of fruits and vegetables. Crit Review Food Science Nutrition, 28: 1-30.

Kashani, M. (1992). Date. Sandooghe Motaleati Khorma Publication, Tehran, Iran, pp: 90-102.

Khan, R.U.; A. Rashid, M.S.; Khan and Farooq, M.A. (2008). Evaluation of date palm cultivars with their monetary returns under ecological zone of dera Ismail Khan. J. Agric. Res., 46: 93-98.

Mehyar, G.F.; El Assi, N.M.; Alsmairat, N.G. and Holley, R.A. (2014). Effect of edible coatings on fruit maturity and fungal growth on Barhidates.Inter. J. of Food Sci. and Technol., 49(11): 2409-2417.

Mortazavi, S.M.H.; Arzani, K. and Arujalian, A.A. (2010). Modified atmosphere packaging of date fruit (Phoenix dactylifera L.) cultivar 'Barhee' in khalal stage Acta Hort. 882: 1063-1070.

Mortazavi, S.M.H.; Arzani, K. and Barzegar, M. (2007). Effect of vacuum and modified atmosphere packaging on the postharvest quality and shelf-life of date fruits in khalal stage. Acta Hort. 736:471-477.

Mortazavi, S.M.H.; Siruie, B. and Mohammadi, F. (2010). Interactive Effects of temperature and 1methylcyclopropene on 'Barhee' date fruit quality picked at khalal stage. Acta Hort. 882: 867- 874.

Mphahlele, R.R.; Fawole, O.A. and Opara, U.L. (2016). Influence of packaging system and long term storage on physiological attributes, biochemical quality, volatile composition and antioxidant properties of pomegranate fruit. Sci. Hort., 211: 140-151.

Ochoa-Velasco, C.E. and GuerreroBeltran, J.A. (2016). The effects of modified atmospheres on prickly pear (Opuntiaalbicarpa) stored at different temperatures. Post. Bio. and Technol., 111:314-321.

Omoigho, S.E. and Ikenebomeh, M.J. (2000). Effect of temperature treatment on the chemical composition of pounded white yam during storage. Food Chem., 71: 215220.

Rizzo, V. and Muratore, G. (2009). Effects of packaging on shelf-life of fresh celery. J. of Food Engi. 9:124-128.

SAS Institute (2008). The SAS System for Windows, release 9.2. Cary NC: SAS Institute.

Tafti, A. G. and Fooladi, M. H. (2005). Changes in physical and chemical characteristic of Mozafati date fruit during development. J. of Bio. Sci., 5: 319-322.

Thompson, K.A. and Abboodi, A.H. (2003). Modified atmosphere packaging, proceedings ofthe international conference on date palm. King Saud Univ., Qassim, Kingdom of SaudiArabia,: 363394.

Wang, T., Gonzalez, A.R., Gbur, E.E. and Aselage, J. M. (1993). Organic acid changes during ripening of processing peaches. J. Food Sci. 58: 631- 632 .

Wills, R., McGlasson, B., Graham, D. and Joyce, D. (1998). Postharvest: An Introduction to the Physiology \& Handling of Fruits, Vegetables and Ornamentals. CAB International Press, Sydney, Australia: 5459.

Zare, Z., M.; Sohrabpour, T. Z. and Fazeli-Kohan, K. G. (2002). Evaluation of invertase $(\beta-$ frutofuranosidase) activity in irradiated Mazafaty dates during storage. Radiat. Phys. Chem., 65: 289291. 
تأثير التعبئة وظروف التخزين المبرد علي الخواص الفيزوكيمائية لثمار البلح البرحي

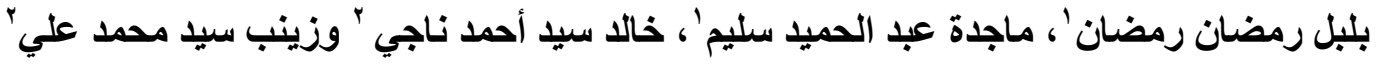

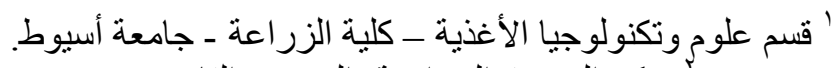

بمركز البحوث الزر اعية الجيزة ـ القاهرة

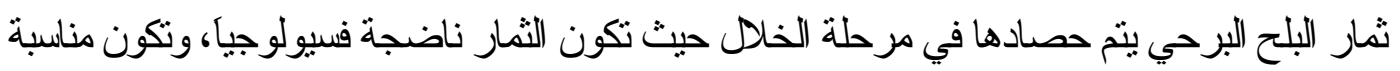
المدخص

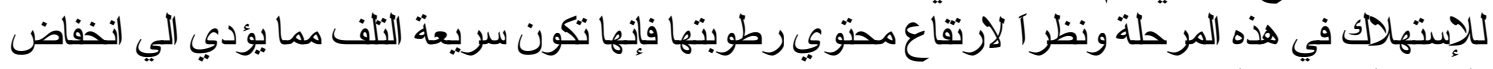
العمر التخزيني لها.

تم در اسة الخو اص الفيزوكيمائية لثمار بلح البرحي (صنف رطب عالب عالي الجودة) و التي تم الحصول

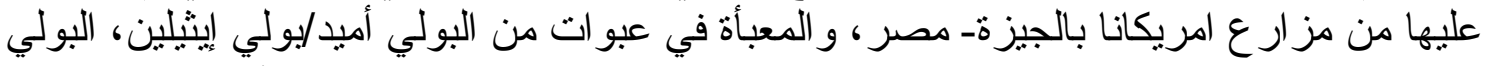

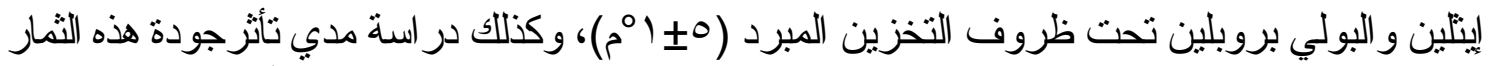

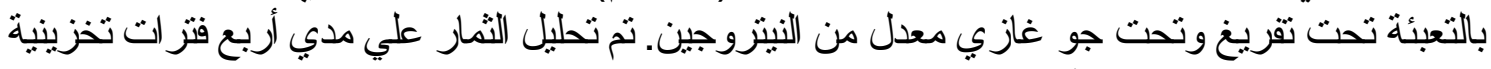

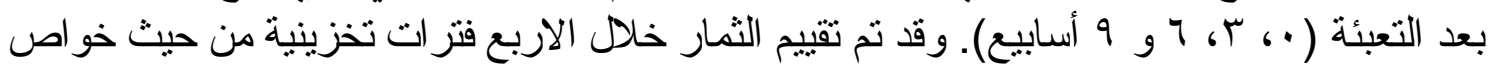

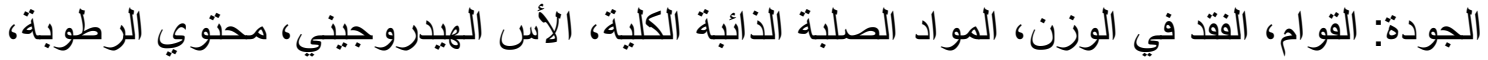
الحموضة و السكريات الكلية.

تبين من النتائج المتحصل عليها أن الثمار بالثماريخ المعبأة في عبو ات من البولي بروبلين تحت

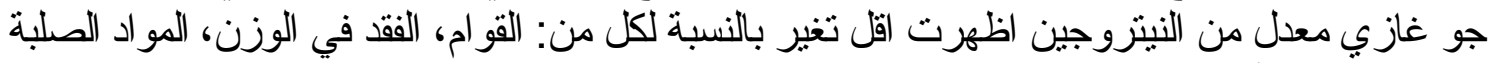

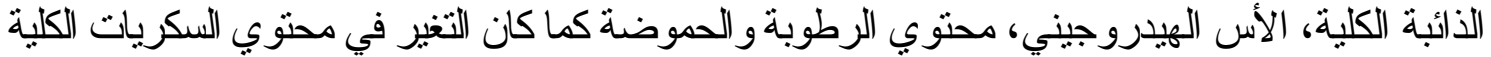

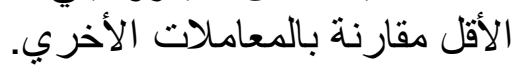

